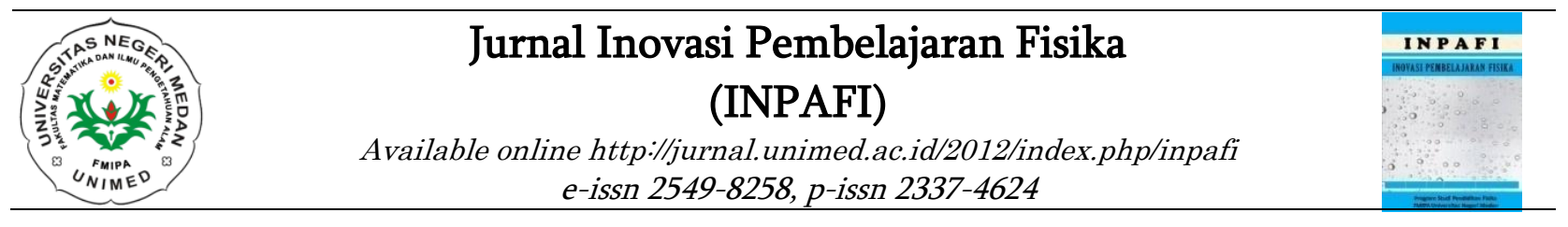

\title{
PENGARUH MODEL PROJECT BASED LEARNING TERHADAP KETERAMPILAN PROSES SAINS FISIKA SISWA PADA MATERI POKOK MOMENTUM DAN IMPULS
}

\author{
Prima Ria R Panggabean dan Jonny Haratua Panggabean \\ Jurusan Fisika FMIPA Universitas Negeri Medan \\ primapanggabean95@gmail.com,gabejhp@gmail.com
}

Diterima: September 2018 Disetujui: Oktober 2018 Dipublikasikan: Nopember 2018

\begin{abstract}
ABSTRAK
Penelitian ini bertujuan untuk mengetahui pengaruh penerapan model project based learning terhadap keterampilan proses sains fisika siswa pada materi pokok momentum dan impuls. Jenis penelitian ini adalah quasi experiment dengan desain two group pre-test-post-test. Pengambilan sampel dilakukan dengan cara random sampling dengan mengambil dua kelas dari tujuh kelas yaitu kelas X MIA-3 sebagai kelas eksperimen dan kelas X MIA-6 sebagai kelas kontrol yang masingmasing berjumlah 33 orang. Instrumen yang digunakan berupa tes keterampilan proses sains berbentuk uraian yang terdiri dari 8 soal yang sudah divalidasi dan lembar observasi untuk mengukur keterampilan proses sains selama proses pembelajaran. Hasil penelitian menunjukkan nilai rata-rata pre-test kelas eksperimen adalah 36,17 dan kelas kontrol adalah 34,09. Setelah pembelajaran selesai diberikan post-test dengan hasil nilai rata-rata kelas eksperimen 71,02 dan kelas kontrol adalah 61,55. Hasil uji hipotesis menggunakan uji beda (uji-t) diperoleh ada pengaruh yang signifikan penerapan model project based learning terhadap keterampilan proses sains fisika siswa pada materi pokok momentum dan impuls.
\end{abstract}

Kata Kunci: project based learning, keterampilan proses sains, momentum dan impuls

\begin{abstract}
This study aims to determine the effect application of model project based learning toward science process skill student physics at the subject matter of Momentum and Impuls. The kind of research is quasi experiment by design two group pre-test-post-test. Sample interpretation was doing by random sampling with take two classes of seven classes like X MIA-3 class as experiment class that aggregate 33 peoples and X MIA-6 class as control class that aggregate 33 peoples. Instrument that use like science process skill test that form essay consist of 8 question that had validity and sheet of observation to measure science process skill as learning process. The research result refer average pre-test value of experiment class is 36,17 and control class is 34,09. After learning had been finished was given post-test with the result average post-test value experiment class is 71,02 and control class is 61,55 . The result hypotheses test use different test (t-test) there was effect significantly application of model Project Based Learning toward science process skill student physics at at the subject matter of Momentum and Impuls.
\end{abstract}

Keyword : project based learning, science process skill, momentum and impulse 


\section{PENDAHULUAN}

Orientasi pembelajaran dalam konteks kurikulum 2013 adalah untuk menghasilkan insan Indonesia yang produktif, kreatif, inovatif, dan efektif melalui penguatan sikap (tahu mengapa), keterampilan (tahu bagaimana), dan pengetahuan (tahu apa). Hal ini dilandasi oleh adanya kesadaran bahwa perkembangan kehidupan dan ilmu pengetahuan abad 21 telah terjadi pergeseran ciri khas dibandingkan dengan abad sebelumnya, yaitu merupakan abad informasi, komputasi, otomasi, dan komunikasi (Abdul, 2014). Jalur yang tepat untuk meningkatkan sumber daya manusia adalah melalui jalur pendidikan. Oleh sebab itu, sudah sepantasnya peningkatan kualitas dibidang pendidikan menjadi aspek utama yang harus dilakukan oleh pemerintah agar melahirkan generasi-generasi bangsa yang memiliki intelektual tinggi, kesadaran dan tanggungjawab yang tinggi serta keterampilan.

IPA merupakan ilmu yang diperoleh melalui pengamatan dan penelitian terhadap gejala-gejala alam. IPA meliputi tiga bidang umum, yaitu fisika, kimia, dan biologi. Fisika adalah ilmu pengetahuan yang paling mendasar, karena berhubungan dengan perilaku dan struktur benda (Giancoli, 2001). Fisika merupakan salah satu mata pelajaran sains yang diajarkan di sekolah sebagai bagian rumpun dalam mencapai kompetensi pengetahuan (kognitif) dan keterampilan (psikomotorik) berupa memahami konsep, kemampuan menerapkan konsep dalam kehidupan seharihari, kemampuan memecahkan masalah, maupun berpikir analitis, kritis, dan kreatif.

Dapat dikatakan hakikat fisika adalah ilmu pengetahuan yang mempelajari gejalagejala melalui serangkaian proses yang dikenal dengan proses ilmiah yang dibangun atas dasar sikap ilmiah dan hasilnya terwujud sebagai produk ilmiah yang tersusun atas tiga komponen terpenting berupa konsep, prinsip, dan teori yang berlaku secara universal. Pengertian tersebut memberikan gambaran bahwa konsep, prinsip dan teori dalam fisika tidak harus dihapal, tetapi dipahami oleh siswa. $\mathrm{Hal}$ ini bertolak belakang dengan kenyataan di lapangan bahwa siswa hanya menghapal konsep dan kurang mampu menggunakan konsep tersebut jika menemui masalah dalam kehidupan nyata yang berhubungan dengan konsep yang dimiliki (Trianto, 2011).

Hasil studi pendahuluan di sekolah SMA Negeri 11 Medan pada tanggal 18 januari 2017 dengan menggunakan instrumen angket yang disebarkan pada 66 siswa kelas X. diperoleh data bahwa 7,57\% (5 siswa) menyukai pelajaran fisika, 36,36\% (24 siswa ) biasa saja terhadap pelajaran fisika. 62,12 \% (41 siswa) menganggap fisika itu adalah pelajaran yang sulit.

Proses pembelajaran di SMA Negeri 11 Medan menurut angket yang dibagikan pada siswa 92\% (61 siswa) pembelajaran dilakukan dengan mencatat dan mengerjakan soal; 8\% (5 siswa) pembelajaran dilakukan dengan berdiskusi dan tanya jawab. Hasil angket juga menunjukkan sebanyak 92\% (33 siswa) siswa menginginkan belajar sambil bermain. Sebanyak $71 \%$ (47 siswa) penyampaian materi fisika oleh guru fisika jelas tetapi sulit dipahami siswa, 38\% (25 siswa) yang menginginkan belajar fisika dengan praktikum dan demonstrasi. Angket yang dibagikan disini didapatilah keterampilan proses sains siswa rendah karena siswa belajar fisika jarang dengan praktikum. Model pembelajaran beliau, cenderung lebih dominan menggunakan pembelajaran konvensional, dengan metode ceramah, latihan, dan penugasan.

Hasil wawancara dengan salah satu guru fisika di SMA Negeri 11 Medan didapatkan hasil belajar siswa terhadap mata pelajaran fisika masih kurang. Pembelajaran yang sering digunakan adalah Pembelajaran konvensional yang berarti berpusat pada guru, dimana guru memberikan ceramah terhadap materi yang diajarkan. Banyak siswa yang bosan dan kurang efektif dalam bertanya dan mengeluarkan pendapat saat proses pembelajaran dan terkadang tidak berminat untuk belajar.

$$
\text { Berdasarkan pemaparan dari }
$$
permasalahan di atas didapatilah adanya kesenjangan antara harapan dan kenyataan. Salah satu alternatif untuk mengatasi permasalahan tersebut adalah melalui 
penerapan model project based learning, yang diharapkan menjadikan siswa aktif dan terampil saat pembelajaran dan mampu meningkatkan hasil belajar fisika. Project based learning merupakan model pembelajaran yang melibatkan siswa secara aktif dalam merancang tujuan pembelajaran untuk menghasilkan produk atau proyek nyata. Proyek-proyek yang dibuat oleh siswa mendorong berbagai kemampuan, tidak hanya pengetahuan atau masalah teknis, tetapi juga keterampilan praktis seperti mengatasi informasi tidak lengkap atau tidak tepat; menentukan tujuan sendiri; dan kerjasama kelompok (Oktadivani,dkk, 2016).

Berdasarkan uraian di atas, model project based learning diperkirakan dapat dijadikan alternatif dalam pembelajaran fisika yang dapat mengembangkan keterampilan proses sains siswa dan diharapkan hasil belajar fisika siswa menjadi lebih baik, khususnya pada materi momentum dan impuls. Dengan demikian peneliti melakukan penelitian dengan tujuan melihat pengaruh model project based learning terhadap keterampilan proses sains fisika siswa pada materi pokok momentum dan impuls.

\section{METODE PENELITIAN}

Penelitian ini dilaksanakan di SMA Negeri 11 Medan semester genap Tahun Pelajaran 2016/2017. Jenis penelitian ini termasuk penelitian quasi eksperimen, yaitu merupakan penelitian yang bertujuan untuk mengetahui ada tidaknya perbedaan akibat pengaruh dari sesuatu yang dikenakan pada subyek yaitu siswa. Pengaruh yang dimaksudkan adalah keterampilan proses sains dengan pendekatan yang telah ditentukan dapat dilihat dari hasil jawaban siswa pada tes keterampilan proses sains.

Adapun langkah-langkah yang dilakukan dalam penelitian adalah : 1)Tahap pertama: Melaksanakan pre-test untuk mengetahui kemampuan awal siswa kelas sampel, 2)Tahap kedua: Membuat rencana pembelajaran dan skenario pembelajaran kemudian melaksanakan pembelajaran pada kelompok sampel yang telah di tetapkan sesuai dengan program rencana pembelajaran. Penilaian ini melibatkan dua kelas yang diberi perlakuan berbeda. Rancangan penelitian two group pre-test post-test design. Penelitian ini sampel kelas diambil secara random sampling. Sampel kelas diambil dari populasi yaitu sebanyak dua kelas, satu kelas dijadikan kelas eksperimen dengan menerapkan model Project Based Learning dan satu kelas lagi dijadikan kelas kontrol dengan menerapkan pembelajaran konvensional. Teknik pengumpulan data yang digunakan adalah dokumentasi, observasi,wawancara, dan tes. Teknik analisis data menggunakan uji normalitas dan uji homogenitas data.

\section{HASIL DAN PEMBAHASAN}

\section{a. HASIL PENELITIAN}

Hasil penelitian ini merupakan data hasil tes keterampilan proses sains siswa. Data keterampilan proses sains diukur dengan menggunakan tes keterampilan proses sains.

Adapun perolehan hasil nilai rata-rata pre-test 34,09 dan post-test 61,55 dikelas kontrol dan di kelas eksperimen. Ditunjukkan pada Gambar 1 dan Gambar 2 :

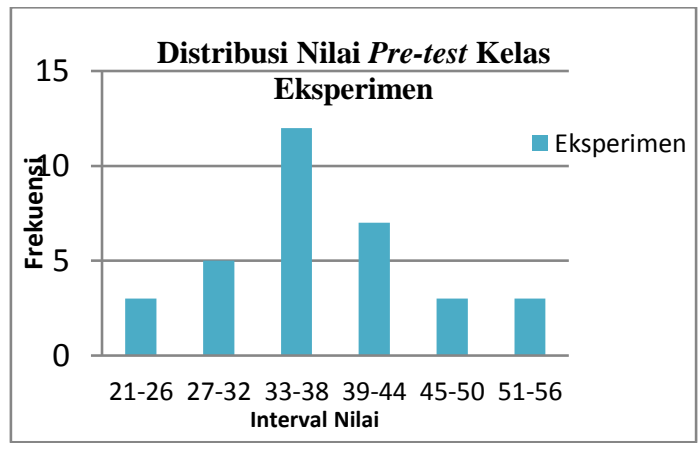

Gambar 1. Data Pre-test kelas Eksperimen 


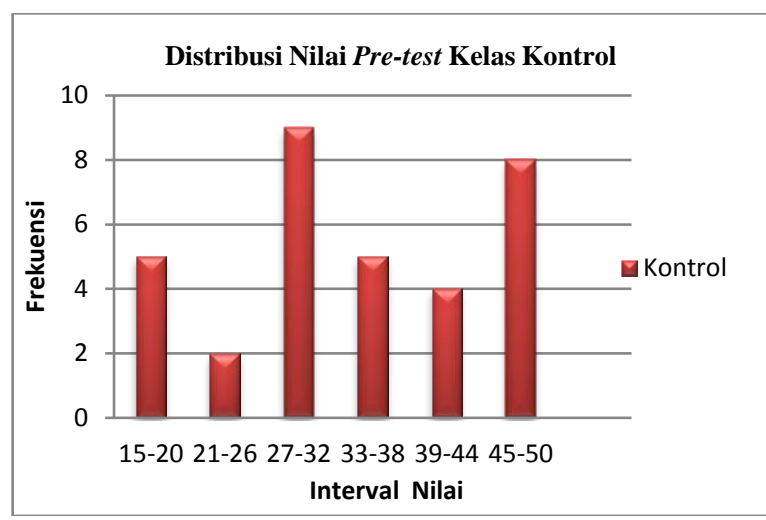

Gambar 2. Data Pre-test kelas Kontrol

Gambar diatas menunjukkan bahwa nilai pre-test pada kelas eksperimen dan kelas kontrol memiliki nilai yang rendah namun nilai kelas eksperimen dan kelas kontrol tidak jauh berbeda.

Data post-test kelas eksperimen dan kelas kontrol ditunjukkan pada Gambar 3 dan Gambar 4 :

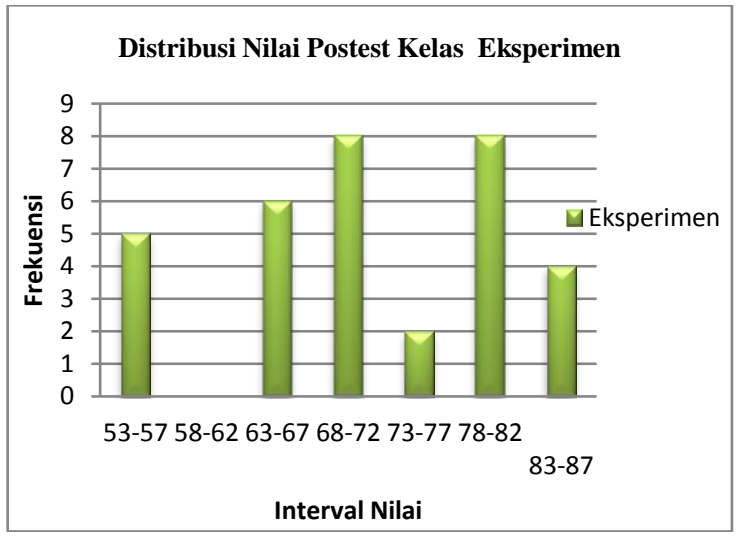

Gambar 3. Data Post-test kelas Eksperimen

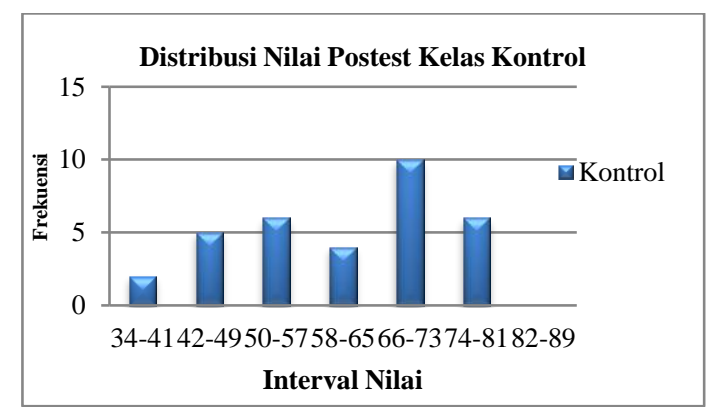

Gambar 4. Data Post-test kelas Kontrol

Penggunaan model project based learning dapat meningkatkan keterampilan proses sains siswa dalam aspek keterampilan dan aktivitas keterampilan proses sains siswa. Ini dibuktikan dengan nilai rata-rata aktivitas keterampilan proses sains siswa pertemuan I adalah 60,03, pertemuan II adalah 69,12, dan pertemuan III adalah 80,52. Ditunjukkan pada Gambar 5 :

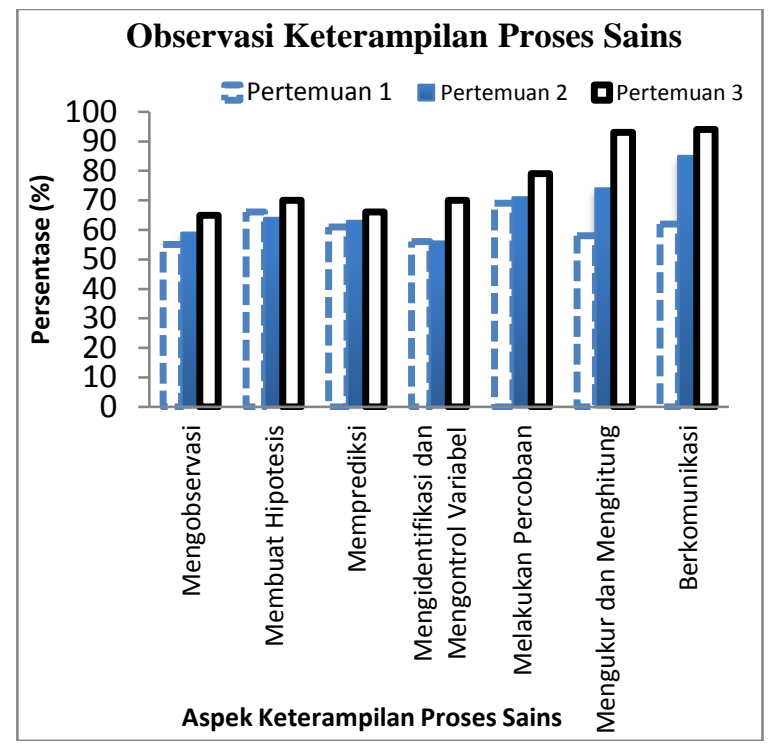

Gambar 5. Data Observasi Keterampilan Proses Sains

Dan nilai rata-rata keterampilan dalam proyek pada pertemuan I adalah 77,27, pertemuan II adalah 78,03, dan pertemuan III adalah 82,58. Sehingga dari hasil rata-rata presentasi keterampilan dan aktivitas keterampilan proses sains siswa di kelas eksperimen dengan menggunakan model Project Based Learning termasuk dalam kriteria aktif. Data penilaian project based learning keterampilan proses sains ditunjukkan pada Gambar 6 :

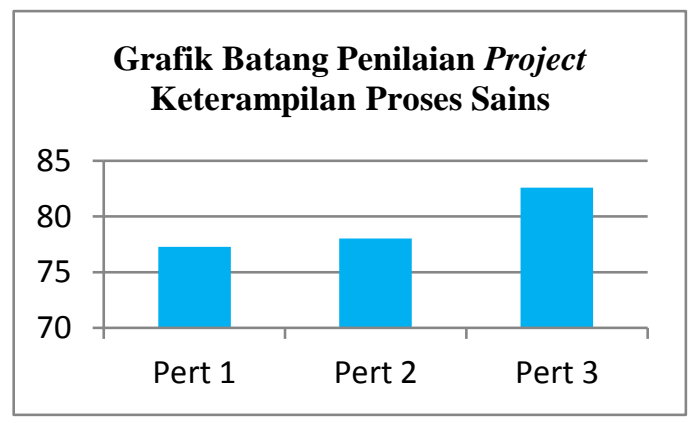

Gambar 6. Data Penilaian Project Keterampilan Proses Sains 


\section{b. PEMBAHASAN}

Hasil penelitian menunjukkan adanya pengaruh model project based learning terhadap keterampilan proses sains siswa pada materi pokok momentum dan impuls. Hal ini dibuktikan dengan nilai post-test keterampilan proses sains siswa di kelas eksperimen lebih unggul dari nilai post-test keterampilan sains siswa dikelas kontrol, yang sebelumnya sudah diketahui bahwa kelas eksperimen dan kelas kontrol memiliki kemampuan awal yang sama.

Tingginya keterampilan proses sains siswa dikelas eksperimen dipengaruhi oleh model Project Based Learning. Pada pembelajaran di kelas model Project Based Learning melibatkan kerja proyek. Melalui pembelajaran berbasis proyek, kreativitas dan motivasi siswa akan meningkat. Pembelajaran berbasis proyek meliputi get an idea, design the project, tune the project, do the project, dan exhibit the project berkaitan dengan materi yang dibahas (Patton, 2012). Penelitian ini senada dengan penelitian yang telah dilakukan peneliti terdahulu Siwa, (2013) menyatakan Berdasarkan hasil penelitian dapat disimpulkan terdapat perbedaan hasil belajar keterampilan proses sains antara kelompok siswa yang mengikuti model pembelajaran proyek dengan kelompok siswa yang mengikuti model pembelajaran konvensional (IB. Siwa, 2013).

Hasil penelitian menggunakan model Project Based Learning ini senada dengan hasil penelitian yang dilakukan Utari Oktadifani, (2016) berdasarkan hasil analisis keterampilan proses sains selama pembelajaran fisika menggunakan model project based learning menunjukkan keterampilan proses sains siswa seperti pada tabel 1, maka keterampilan proses sains tersebut termasuk pada kriteria sangat baik. Hal ini karena rangkaian kegiatan pembelajaran dengan model project based learning sangat mendorong siswa untuk aktif dan terampil dalam kegiatan pembelajaran dengan siswa memahami sendiri pengetahuannya melalui kegiatan mendesain rancangan proyek dan dalam pelaksanaannya siswa dapat membangun pengetahuan melalui pengalaman bereksperimen secara nyata dengan kelompok masing-masing. Sehingga keterampilan proses sains siswa dapat meningkat (Utari Oktadifani, 2016). Penelitian lain juga dilakukan oleh Siti Rodliyatin, (2017) menyatakan Hasil penelitian ini sejalan dengan penelitian yang dilakukan yang menunjukkan hasil belajar siswa kelas eksperimen pada pembelajaran berbasis proyek pada mata pelajaran menggambar teknik lebih baik daripada hasil belajar siswa kelas kontrol (Siti Rodliyati, 2017). Penelitian lain juga dilakukan oleh Sugiartawan Bayu Permana Gede, (2015) menyatakan penerapan model project based learning pada penerapan rangkaian elektronika di kelas XI TAV 1 SMK N 3 Singaraja dapat meningkatkan hasil belajar siswa, hal itu dapat dilihat dari peningkatan ketuntasan klasikal yang diperoleh sebelum diterapkannya model project based learning sebesar 56\% sedangkan setelah diterapkannya model project based learning selama dua siklus didapat hasil yaitu pada siklus I ketuntasan klasikal didapat sebesar $72 \%$. dan pada akhir siklus II yang mana sebesar $88 \%$. Dengan peningkatan rata-rata hasil belajar siswa dari 75.07 pada siklus I menjadi 76.33 pada Siklus II Sugiartawan Bayu Permana Gede., dkk (2015).

Model Project Based Learning membuat keterampilan proses sains siswa lebih baik dibandingkan dengan pembelajaran konvensional. Namun peneliti mangakui bahwa hasil keterampilan proses sains siwa tidak begitu tinggi dan hanya memiliki selisih nilai 9,47 poin.

\section{KESIMPULAN DAN SARAN}

Berdasarkan hasil penelitian yang dilakukan menggunakan model Project Based Learning terhadap keterampilan proses sains siswa pada materi momentum dan impuls maka dapat disimpulkan bahwa :

1) Nilai rata-rata keterampilan proses sains siswa dikelas eksperimen yang menggunakan model Project Based Learning adalah 71,02, 
2) Nilai rata-rata keterampilan proses sains siswa dikelas kontrol menggunakan pembelajaran konvensional adalah 61,55 ,

3) Berdasarkan analisis hasil uji thitung adalah 3,46 sedangkan tabel adalah 2,0006 pada taraf nyata 0,05 artinya $\mathrm{H}_{\mathrm{a}}$ diterima dimana thitung > ttabel $(3,46>2,0006)$ sehingga diperoleh kesimpulan bahwa ada pengaruh dari penerapan model Project Based Learning terhadap keterampilan proses sains siswa pada materi momentum dan impuls,

4) Hasil nilai project keterampilan proses sains rata-rata diperoleh dari setiap pertemuan I adalah 77,27, pertemuan II adalah 78,03, dan pertemuan III adalah 82,58 ada perkembangan dengan kategori baik,

5) Nilai aktivitas keterampilan proses sains siswa rata-rata pertemuan I adalah 60,03, pertemuan II adalah 69,12 , dan pertemuan III adalah 80,52, dengan kategori baik.

Kesimpulan yang diperoleh pada penelitian ini, maka peneliti mempunyai beberapa saran yaitu :

1) Peneliti yang ingin meneliti dengan menggunakan model Project Based Learning lebih lanjut lagi sebaiknya menyesuaikan dengan materi yang berhubungan dengan project,

2) Untuk peneliti selanjutnya jika ingin membagikan kelompok dalam model ini jangan terlalu banyak anggota satu kelompok paling banyak itu 4 orang, agar berjalan lebih efektif,

3) Peneliti harus memiliki observer dalam melakukan penelitian karena dapat membantu proses pembelajaran lebih kondusif,

4) Peneliti agar membuat perencanaan dengan sejelas-jelasnya dan benar-benar mempersiapkan segala perangkat yang akan dibutuhkan selama pembelajaran,

5) Peneliti juga menyarankan agar memperkenalkan terlebih dahulu alat/bahan yang akan digunakan dalam merangkai sebuah produk kepada siswa agar siswa tidak bingung.

\section{DAFTAR PUSTAKA}

Arsyad, A., (2007), Media Pembelajaran, PT. Raja Grafindo, Jakarta.
Gede, P.S.,B., Nurhayata., Sutaya, W., (2015),

Penerapan Model Project Based Learning Untuk Meningkatkan Hasil Belajar Siswa Pada Pelajaran Penerapan Rangkaian Elektronika Kelas Xi Tav 1 Di SMK Negeri 3 Singaraja, Jurnal PTE Universitas Pendidikan Ganesha Jurusan Pendidikan Teknik Elektro, 4(1):8-9.

Giancoli, D.,C., (2001), Fisika Dasar Jilid I Edisi Kelima, Erlangga, Jakarta.

Oktadifani, U., Djoko, A.L., dan Subiki., (2016), Pengaruh Model Project Based Learning Terhadap Keterampilan Proses Sains Dan Hasil Belajar Siswa Dalam Pembelajaran Fisika Di SMA, Jurnal Pembelajaran Fisika, 5(2):110.

Oktaviani, S. N., dan Surmadi, Y., (2016), Peranan Perangkat Pembelajaran Fisika Berbasis Desain untuk Meningkatkan Pemahaman Konsep dan Keterampilan Proses Siswa SMA,Unnes Physics Education Journal, 5(3):1-11.

Patton, A., (2012), Work that matters The Teacher's Guide to Project-Based Learning, Paul Hamlin Foundation, U.K.

Rodliyatin, S., Subiki., Harijanto A., (2017), Pengaruh Model Pembelajaran Berbasis Proyek Dengan Memanfaatkan Lingkungan Sekitar Terhadap Hasil Dan Aktivitas Belajar Fisika Siswa (Studi Pada Materi Fluida Di Smk Negeri 2 Jember), Jurnal Pembelajaran Fisika, 5(4):409.

Siwa, IB., Muderawan, I.W., Tika, I.N., Pengaruh Pembelajaran Berbasis Proyek Dalam Pembelajaran Kimia Terhadap Keterampilan Proses Sains Ditinjau Dari Gaya Kognitif Siswa, eJournal Program Pascasarjana Universitas Pendidikan Ganesha Program Studi IPA, 3:10.

Trianto., (2011), Model Pembelajaran Terpadu, Bumi Aksara, Jakarta. 